\title{
REMOTE-SENSING BASED GROUNDWATER RECHARGE ESTIMATES IN THE DANUBE-TISZA SAND PLATEAU REGION OF HUNGARY
}

\author{
JÓZSEF SZILÁGYI ${ }^{1,2 *}$, ÁKOS KOVÁCS ${ }^{11}$, JÁNOS JÓZSA ${ }^{1)}$ \\ ${ }^{1)}$ Department of Hydraulic and Water Resources Engineering, Budapest University of Technology and Economics, Muegyetem \\ Rakpart 3-9, Budapest, H-1111, Hungary; Mailto: jszilagyi1@unl.edu \\ ${ }^{2)}$ School of Natural Resources, University of Nebraska-Lincoln, 3310 Holdrege Street HH625, 68583, Lincoln, Nebraska, USA.
}

Mean annual recharge in the Danube-Tisza sand plateau region of Hungary over the 2000-2008 period was estimated at a $1-\mathrm{km}$ spatial resolution as the difference of mean annual precipitation $(P)$ and evapotranspiration $(E T)$. The ET rates were derived from linear transformations of the MODIS daytime land surface temperature $\left(T_{s}\right)$ values with the help of ancillary atmospheric data (air temperature, humidity, and sunshine duration). The groundwater under the sand plateau receives about $75 \pm 50 \mathrm{~mm}$ of recharge annually (the plus/minus value is the associated error, resulting from an assumed 5\% error in both the $P$ and $E T$ values), which is about $14 \pm 9 \%$ of the regional mean annual $P$ value of $550 \mathrm{~mm}$. The largest continuous region with elevated recharge rates (about $180 \pm 50 \mathrm{~mm} \mathrm{a}^{-1}$ or $30 \pm 8 \%$ of $P$ ) occur in the south-western part of the plateau due to more abundant precipitation (around $580 \mathrm{~mm} \mathrm{a}^{-1}$ ), while recharge is the smallest (about $40 \pm$ $40 \mathrm{~mm} \mathrm{a}^{-1}$ or $7 \pm 7 \%$ of $P$ ) under forested areas. Typically, lakes, wetlands, river valleys, and certain afforested areas in the north-central part of the region act as discharge areas for groundwater.

KEY WORDS: Groundwater Recharge, MODIS Data, Danube-Tisza Sand Plateau.

József Szilágyi, Ákos Kovács, János Józsa: DOPLŇOVANIE PODZEMNÝCH VÔD PIESOČNATEJ PLOŠINY MEDZI RIEKAMI DUNAJ A TISA, URČENÉ Z ÚDAJOV DIALKOVÉHO PRIESKUMU. J. Hydrol. Hydromech., 60, 2012, 1; 21 lit., 6 obr., 1 tab.

Priemerný ročný úhrn doplňovania podzemných vôd plošiny zloženej z pieskov medzi riekami Dunaj a Tisa s rozlíšením $1 \mathrm{~km}$, pre roky 2000-2008 bol určený ako rozdiel medzi priemerným ročným úhrnom zrážok $(P)$ a evapotranspiráciou $(E T)$. ET bolo určené z lineárnej transformácie teploty povrchu počas dňa $\left(T_{s}\right)$ získanej systémom MODIS pomocou údajov o vlastnostiach atmosféry (teplota vzduchu, vlhkost' vzduchu a trvanie slnečného svitu). Podzemná voda pod pieskovým masívom dostáva ročne asi $75 \pm 50 \mathrm{~mm}$ vody (znamienka plus/mínus znamenajú chybu, vyplývajúcu z predpokladanej 5\% chyby hodnôt $P$ a $E T$ ), ktorá je asi $14 \pm 9 \%$ regionálnej priemernej ročnej hodnoty $P$, ktorá je $550 \mathrm{~mm}$. Najväčšia spojitá oblast' so zvýšeným doplňovaním podzemnej vody (približne $180 \pm 50 \mathrm{~mm}$ za rok alebo $30 \pm 8 \% P$ ) sa nachádza v juhozápadnej časti plató a je dôsledkom vyššieho ročného úhrnu zrážok (okolo $580 \mathrm{~mm}$ ), doplňovanie je nižšie v zalesnených oblastiach (okolo $40 \pm 40 \mathrm{~mm}$, alebo $7 \pm 7 \% P$ ). Jazerá, mokrade, rieky a niektoré zalesnené oblasti v strednej a severnej časti tejto oblasti drénujú podzemné vody.

KLÚČOVÉ SLOVÁ: doplňovanie podzemných vôd, MODIS, plató Dunaj-Tisa.

\section{Introduction}

The Danube-Tisza interfluvial sand plateau of Hungary (Fig. 1) has been in the focus among water resources and agricultural managers for several decades due to its declining groundwater levels. Since the 1970's, the groundwater table in the region has been sinking steadily, reaching a new equilibrium by the mid 1990's, about 2-3 m below its previous level (Pálfai, 2010). The reasons for this decline have been identified (Szilágyi and
Vörösmarty, 1997; Pálfai, 2010) as climatic (predominantly a less favorable precipitation regime between 1970-1990), and man-made (increases in forest cover due to planned afforestation and an increase in semi-confined groundwater extraction leading to induced replenishment from the overlying unconfined aquifer). The relative weights of the above causes are still debated. Based on a complex surface water-ground water model of the region, Szilágyi (1994), Szilágyi and Vörösmarty (1997) estimated the undisturbed (i.e., before the 1970's) 
mean annual groundwater recharge to be about 50 $\mathrm{mm} \mathrm{a}^{-1}$. In the present study this recharge estimate is revisited for the 2000-2008 period, based on the latest developments in remote sensing technology for water resources applications (Szilágyi and $\mathrm{Ko}$ vács, 2010, 2011).

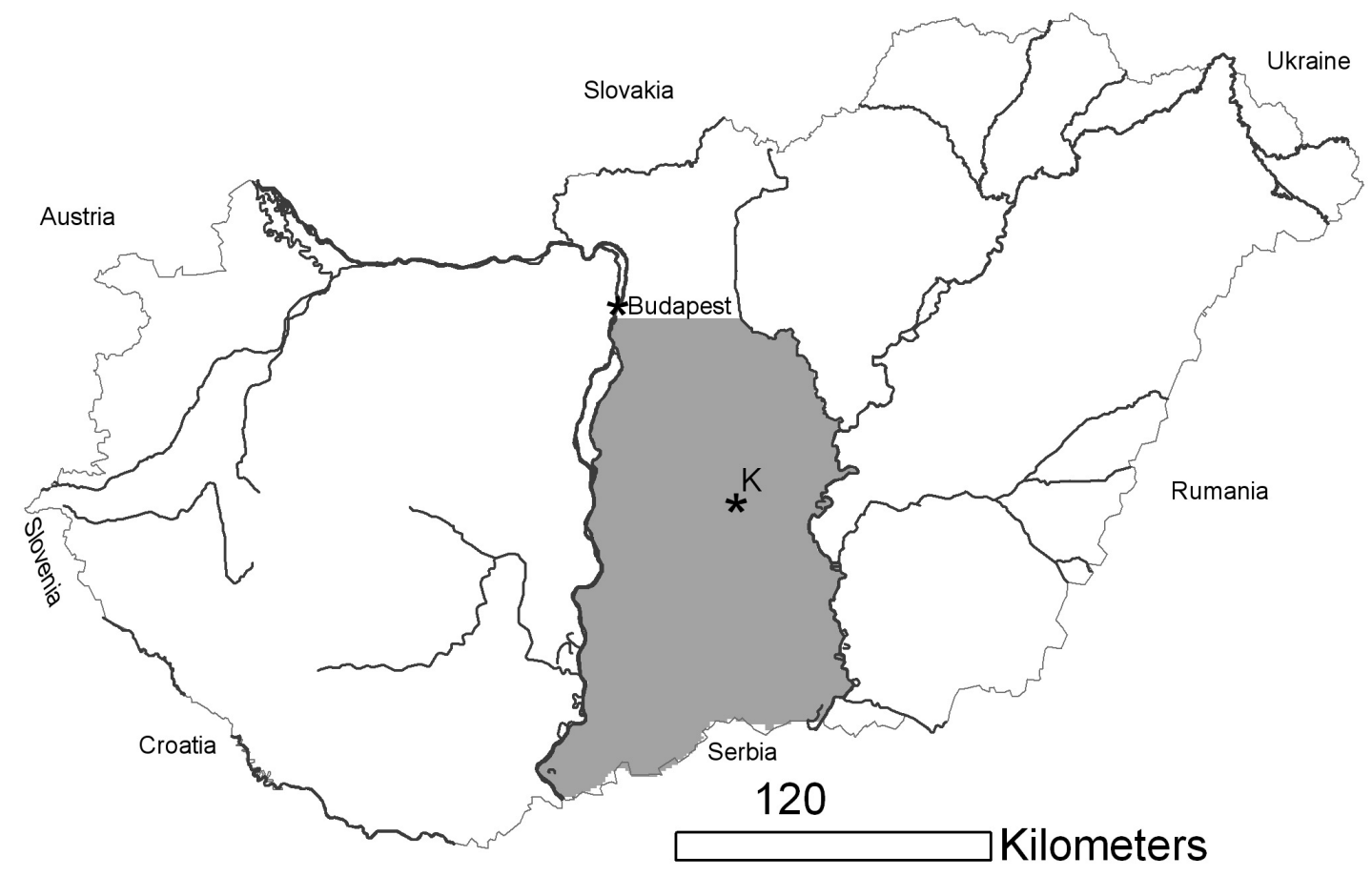

Fig. 1. Location of the sand plateau region within Hungary. The letter $\mathrm{K}$ marks the town of Kecskemét for which climate data is displayed in Tab. 1.

\section{Study-site description}

The sand plateau region of Hungary has an approximate (depending on where the northern limit is drawn) extent of $15000 \mathrm{~km}^{2}$. It is bordered by the Danube from the west, by the Tisza and Zagyva Rivers from the east and north-east, respectively, by the Gödöllö Hills from the north, and by the state border in the south (Fig. 2). The plateau is about $30-50 \mathrm{~m}$ higher than the flanking flood plains and due to its porous sandy soils and relatively smooth relief most of the annual precipitation of about 550 $\mathrm{mm}$ (Fig. 3) seeps into the ground (to contribute to deep percolation or evapotranspiration), resulting in negligible surface runoff. The groundwater table is typically within 3-6 $\mathrm{m}$ of the ground. The unconfined and the underlying semi-confined aquifer are connected by a semi-permeable aquitard allowing for seepage between the two aquifers. The climate is continental, with a mean annual temperature of about $10{ }^{\circ} \mathrm{C}$ and with precipitation more or less evenly distributed throughout the year (Péczely, 1981) expressing a slight maximum in the spring/early summer and a minimum in winter (Tab. 1). Dominant land use in the area is agricultural, with a significant presence of forests (most of them planted), which doubled in extent over the past 80 years, to reach $20-25 \%$ of the total area by 2000.

The porous sand plateau, due to its minimal surface runoff, and flat-to-rolling topography is an ideal place to estimate mean annual recharge rates as the difference in precipitation and evapotranspiration (ET) over a sufficiently long period so that the change in soil moisture becomes negligible in comparison with the cumulative fluxes across the surface. The Moderate Resolution Imaging Spectroradiometer (MODIS) data, freely available from the internet (http://modis.gsfc.nasa.gov/) is almost ideal for the present purpose because it has been collected over a decade now at a nominal spatial resolution of about $1 \mathrm{~km}$. With the help of MODIS daytime surface temperature and ancillary climate data, ET at 1-km resolution has been mapped for Hungary by Szilágyi and Kovács (2010, 2011). A short summary of the approach is discussed below. 


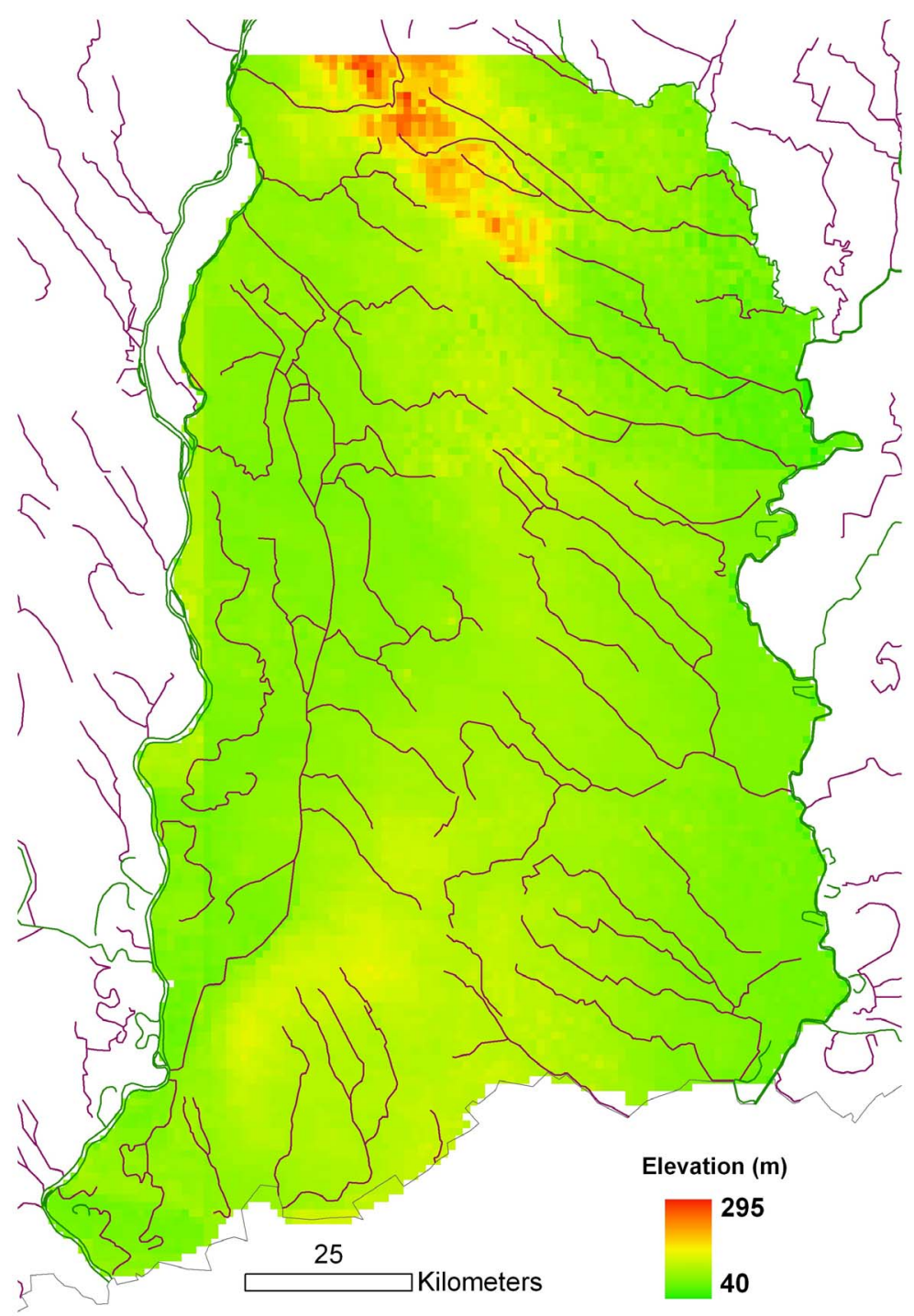

Fig. 2. Elevation and stream network of the sand plateau.

\section{Description of the ET mapping approach}

Based on standard climate data, Morton et al. (1985) presented an algorithm (called the WREVAP model) for estimating regionally representative $E T$ rates for periods longer than 5 days. Szilágyi and Józsa (2009), Szilágyi et al. (2011) devised a method of disaggregating the regional $E T$ values into spatially variable $E T$ rates based on the assumption that at a large enough scale (i.e., at or larger than $1 \mathrm{~km}$ ) where surface heterogeneities of a rolling terrain become largely smoothen out, surface temperatures are proportional to the actual $E T$ rates, since evaporation is an endothermic process, providing an effective cooling (due to the high latent heat of vaporization) of the evaporating sur- face. The spatial disaggregation of the regionally representative evapotranspiration rate, $\langle E T\rangle$, is based on a linear transformation of the 8-day composited MODIS daytime surface temperature $\left(T_{s}\right)$ values into pixel $E T$ rates. The transformation requires the specification of two anchor points in the $T_{s}$ versus $E T$ plane. The first anchor point is defined by the spatially averaged daytime surface temperature, $\left\langle T_{s}\right\rangle$, and the corresponding regionally representative $E T$ rate, $\angle E T>$, from WREVAP, using spatially averaged values of the required climate variables. The second anchor point comes from the coldest, or a spatial average of the coldest, pixel values, $\left\langle T_{s w}\right\rangle$, within the region and the corresponding wet environment evaporation rate, out of consideration that the coldest pixels are the wettest, 


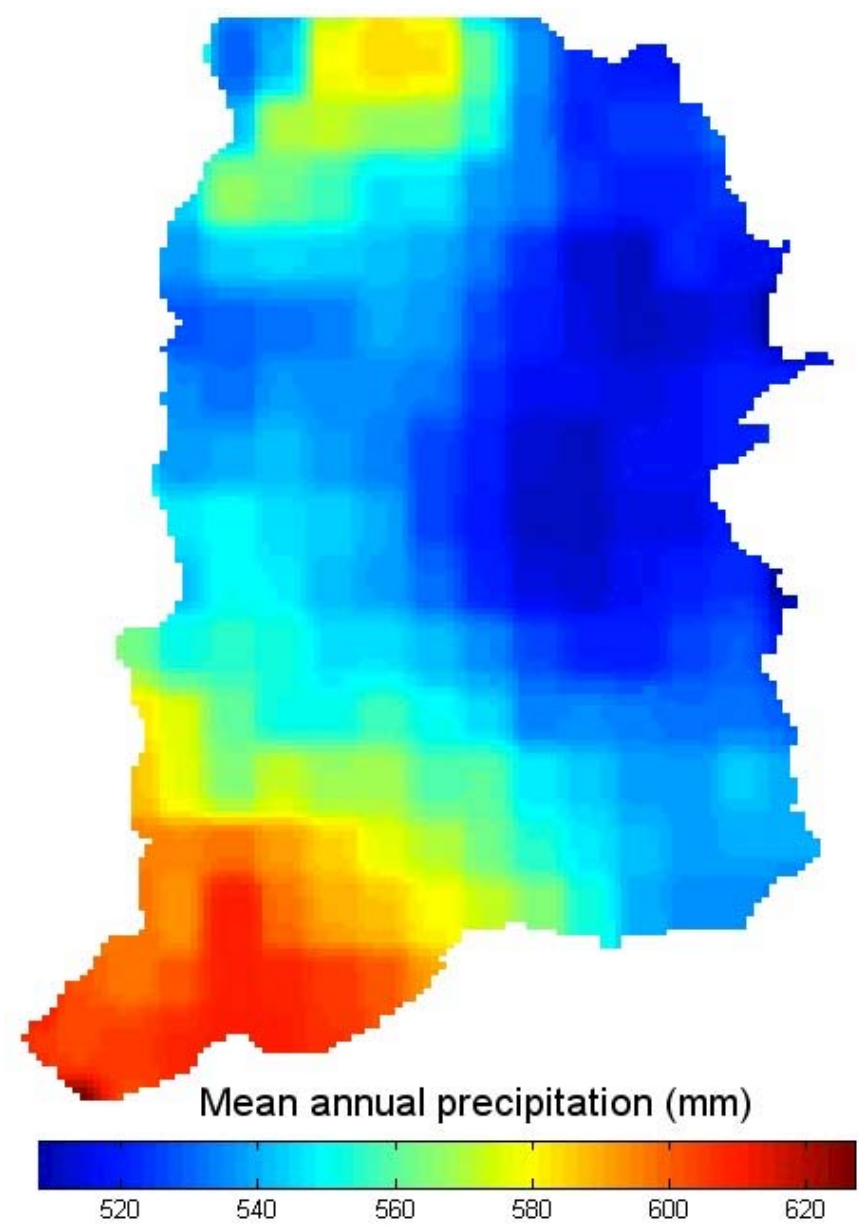

Fig. 3. Period averaged (2000-2008) mean annual precipitation rates [mm] over the sand plateau.

$\mathrm{T}$ a b $1 \mathrm{e} 1$. Long-term mean monthly precipitation $[\mathrm{mm}]$ and air temperature $\left[{ }^{\circ} \mathrm{C}\right]$ values at Kecskemét (Fig. 1), near the center of the Danube-Tisza region (after Péczely, 1981). The precipitation values in parenthesis are for the 2000-2008 period.

\begin{tabular}{l|l|l|l|l|l|l|l|l|l|l|l|l}
\hline & Jan & Feb & Mar & Apr & May & Jun & Jul & Aug & Sep & Oct & Nov & Dec \\
\hline Temperature & -1.7 & 0.1 & 5.1 & 10.5 & 16 & 19.3 & 21.4 & 20.6 & 16.3 & 10.6 & 4.6 & 0.6 \\
Precipitation & 26 & 29 & 32 & 45 & 56 & 55 & 48 & 45 & 46 & 48 & 50 & 37 \\
& $(27)$ & $(32)$ & $(35)$ & $(39)$ & $(44)$ & $(67)$ & $(70)$ & $(53)$ & $(46)$ & $(32)$ & $(35)$ & $(36)$ \\
\hline
\end{tabular}

evaporating at the wet environment $E T$ rate, $E_{w}$ (Priestley and Taylor, 1972). Note that at the 1-km scale of the MODIS pixels this is the largest evaporation rate possible (Brutsaert, 1982). The two points define the linear transformation of the $T_{s}$ pixel values into $E T$ rates for each 8-day period, or, as was done by Szilágyi and Józsa (2009) and repeated here, for each month by employing monthly means of the required variables. The resulting $T_{s}$ versus $E T$ line each month is extended toward the highest $T_{s}$ values, since in about half the number of the pixels $E T$ is less than the regional ET. A monthly time-step is ideal since most of the watershed or large - scale hydrologic/ecological models work at this time-resolution, plus a monthly averaging further reduces any lingering cloud effect in the 8day composited $T_{s}$ values. The method produces ET estimates typically within $10 \%$ of measured monthly or water-balance derived annual and multiannual values (Móricz, 2010). For further information and validation of the method, see Szilágyi and Kovács $(2010,2011)$ and Szilágyi et al. (2011).

8-day composited MODIS daytime surface temperature data were collected for Hungary over the 2000-2008 period and were averaged for each month to yield one surface temperature per pixel per month. Mean annual precipitation, mean monthly air temperature, specific humidity as well as sunshine duration values were provided by the Hungarian Meteorological Service in the form of 
grid-data. The transformations were performed from March till November each year, because in the winter-time with possible patchy snow cover on the ground the quasi-constant surface net energy assumption of the $T_{s}$ versus $E T$ transformations break down (Szilágyi and Józsa, 2009). This does not seriously hinder the calculation of annual ET values, since $E T$ in Hungary is small from December through February due to typical air temperatures around the freezing point and dormant vegetation.

\section{Mapping mean annual recharge}

Mean annual recharge is estimated as the difference in mean annual precipitation $(P)$ and $E T$ due to the special characteristics (i.e., flat-to-rolling terrain, highly permeable sandy soils) of the sand plateau region of Hungary. Both variables are obtained with a 5\% accuracy at best (Dingman, 2002). After extensive testing with data from four continents, Morton reported (Morton, 1983) the regionally representative multi-year ET estimates of WREVAP to agree within $10 \%$ of water-balance data, which, considering the possible error in areal precipitation estimates and stream discharge measurements, is a considerably good estimate. Note that due to the construction of the $T_{s}$ versus $E T$ transformation, the pixel $E T$ values, when averaged over a large area, yield the regional ET value. However, a $5 \%$ error in the precipitation and $E T$ variables, occurring independently may lead to a $10 \%$ error in the $P$ minus $E T$ value, and considering that $E T$ (with a regionally averaged mean annual rate of about $470 \mathrm{~mm}$ ) in the sand plateau is between 80 $90 \%$ of precipitation at most locations (Fig. 4), it can lead to a $\pm 45-95 \%$ error in the resulting recharge estimates. To characterize this uncertainty, an assumed 5\% error will be kept in the mean annual $P$ and $E T$ estimates throughout the study. The present estimation of the mean annual recharge rates assumes no significant trends in soil moisture (thus, in the groundwater table elevations) over the study period of 2000-2008, which is valid to a large degree (Pálfai, 2010), since after around 1995 (till present) the groundwater table stabilized at a level of about 2-3 $\mathrm{m}$ lower than was previously observed, i.e., before the 1970's.

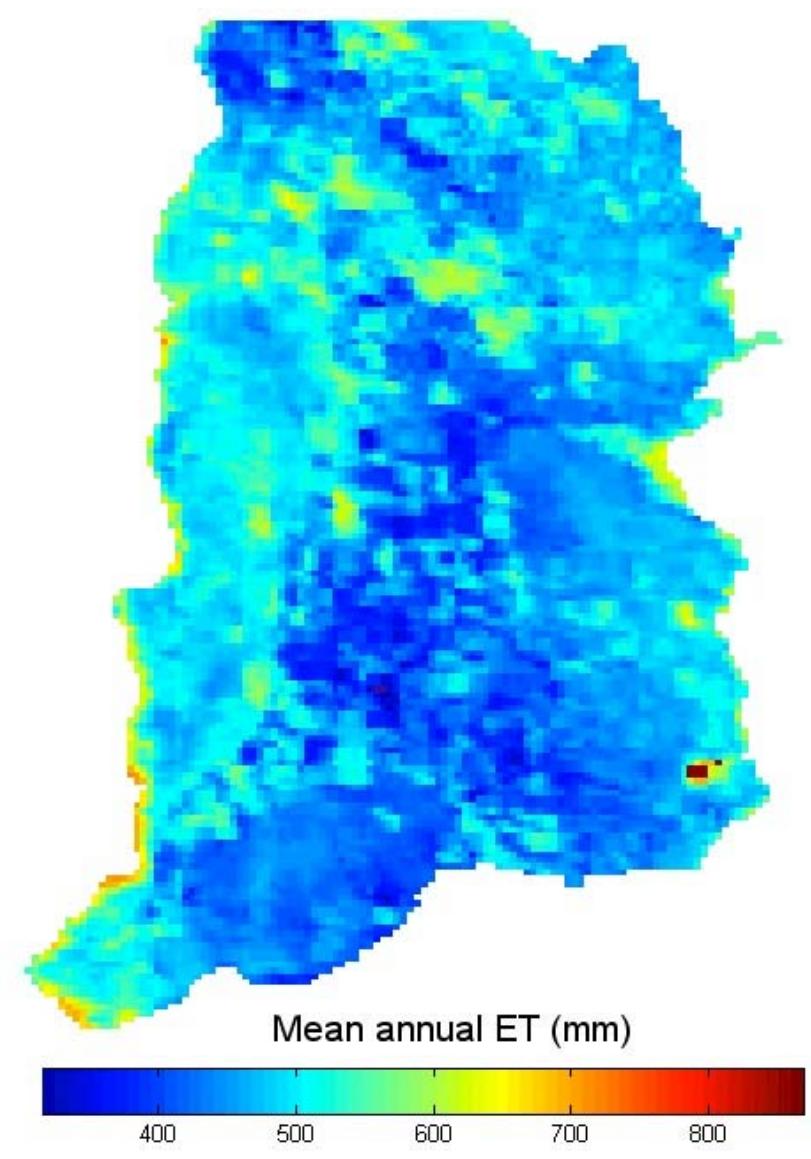

Fig. 4. Estimated period averaged (2000-2008) mean annual ET rates [mm] over the sand plateau. 


\section{Results and discussions}

Distribution of the mean annual recharge rates to the groundwater over the study area is displayed in Fig. 5. The mean annual recharge rate is $75 \pm 50$ $\mathrm{mm}$, which is about $14 \pm 9 \%$ of the precipitation the area receives. The largest continuous area with the highest rates $\left(150 \pm 50-200 \pm 50 \mathrm{~mm} \mathrm{a}^{-1}\right)$ is found in the south-western part of the region, where precipitation rates are the largest (Fig. 3), forest cover is scarce (Fig. 6), and depth to groundwater is large (> $5 \mathrm{~m}$, Pálfai (2010)). From a comparison of Fig. 6 with a depth-to-groundwater map of Pálfai (2010), it can be stated that the estimated recharge rates are the largest where depth to the groundwater table is relatively large $(>3 \mathrm{~m})$ and the land cover is not forest. From an analysis of the ET and recharge rates, according to land cover (obtained from the CORINE $(E E A$, 1994) data set at http://www.eea.europa.eu/themes/landuse/ interactive/clc-download), ET is largest, about 505 $\mathrm{mm} \mathrm{a}^{-1}$, over deciduous forests, therefore, recharge is the smallest, about $40 \pm 40 \mathrm{~mm} \mathrm{a}^{-1}$. Naturally, forests with their more developed, dense root system can capture a larger part of the infiltrated water than other land cover types. Often, the root system of vegetation can be so developed and/or the groundwater-table so close to the surface, that it can tap the saturated zone, thus leading to elevated ET rates, frequently surpassing the precipitation rate the area receives. Fig. 6 displays the locations (in magenta) where $E T$ is estimated to be larger than precipitation. On many locations these groundwater discharge areas overlap with a forest cover (deep green areas), especially in the north-central part of the study region. Typically, these groundwater discharge areas appear, beside these forested locations, under lakes, marshes, wetlands, and river valleys where the groundwater table is close to the surface $(<3 \mathrm{~m})$ thus letting almost any vegetation type to reach it.

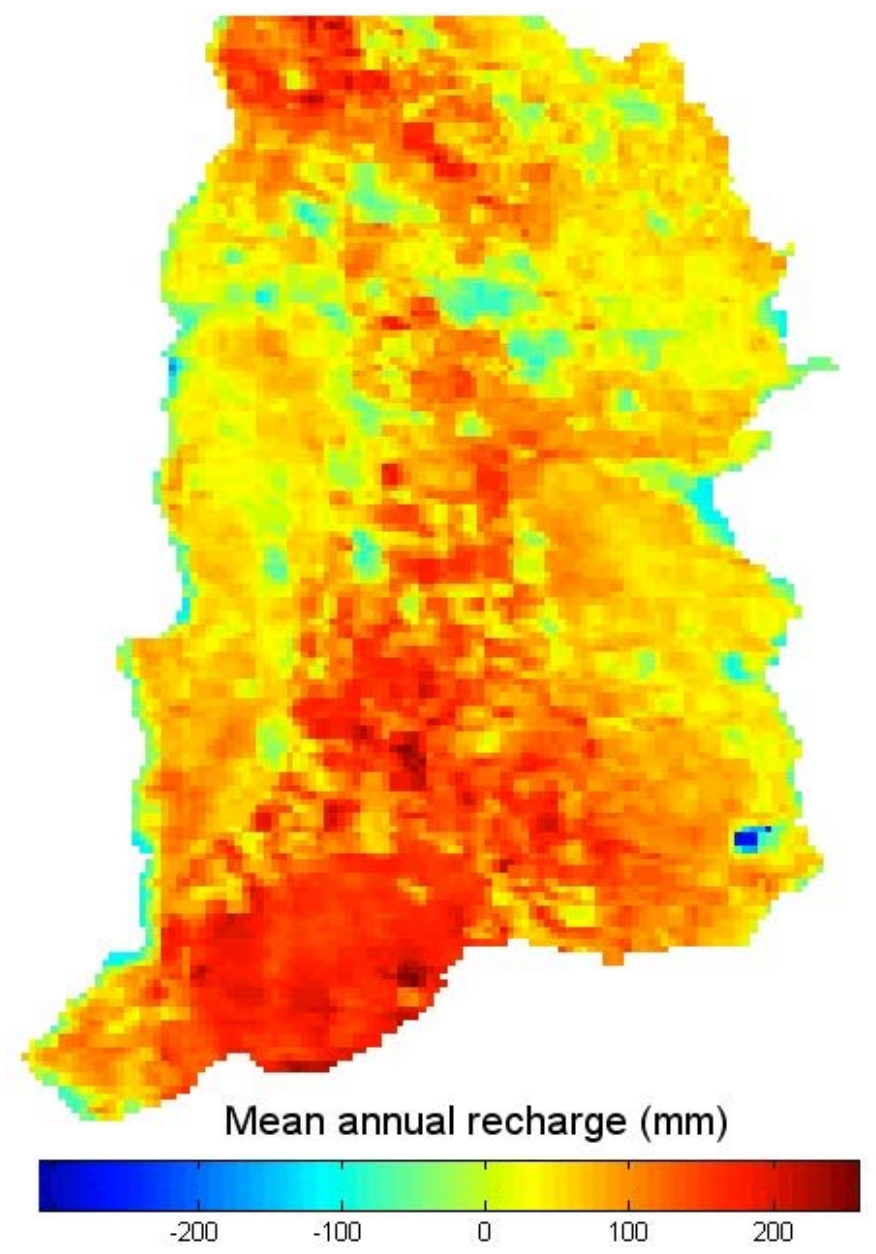

Fig. 5. Mean annual recharge [mm], estimated as the difference in period averaged (2000-2008) mean annual precipitation and ET over the sand plateau. 


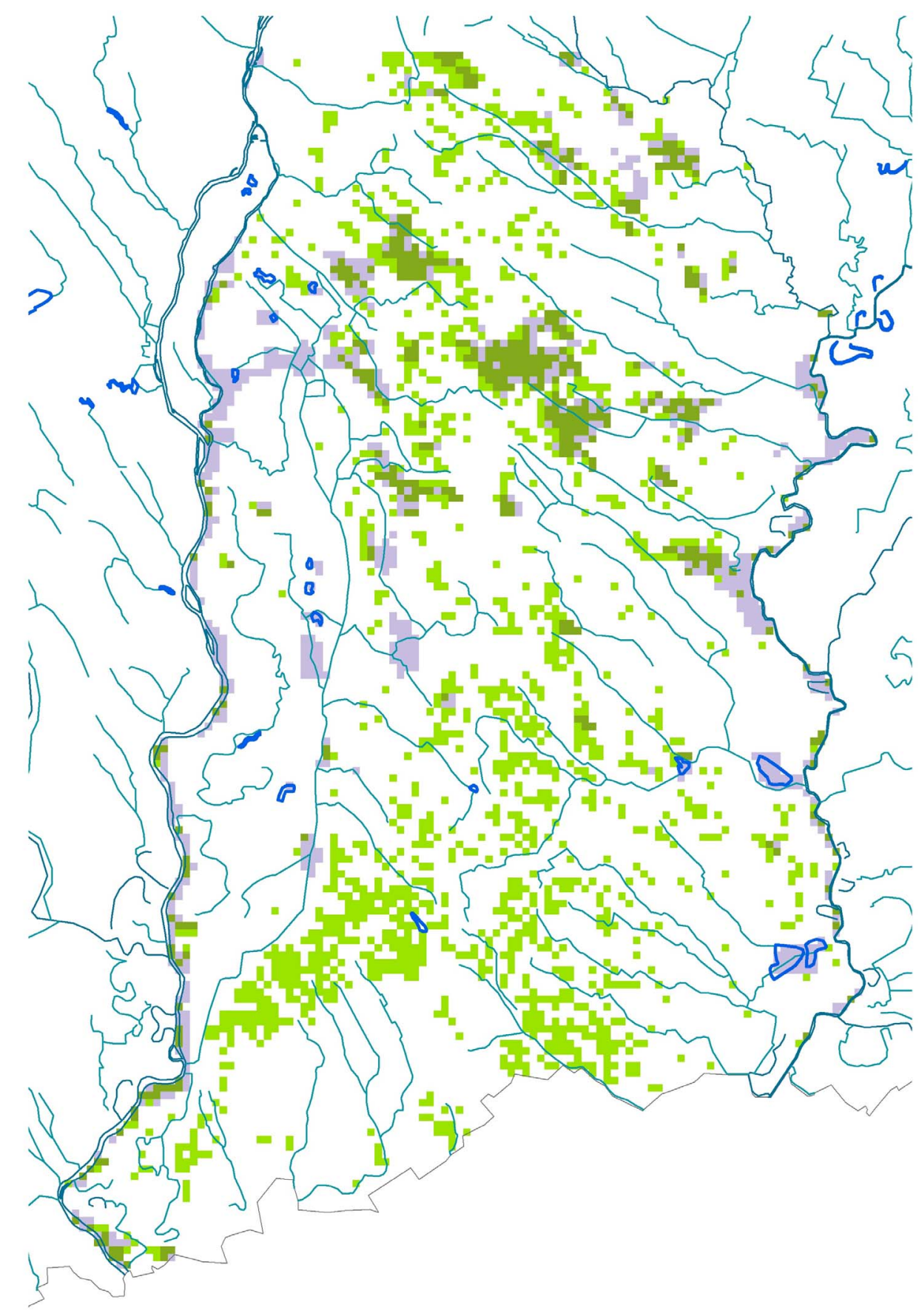

Fig. 6. Distribution of the groundwater-discharge areas (i.e., estimated recharge is negative, in magenta) together with the forests (light green). The forest is indicated in dark green where the two areas overlap. Lakes are outlined in vivid blue color.

Having a groundwater ridge around the central axis of the sand plateau, forests can only consume more water than they receive from precipitation if they create a local depression in the groundwater table, to induce groundwater flow directed toward them, which thus supplies the difference in $E T$ and precipitation. In fact, this has been reported by $M a$ jor (1976, in Stelczer, 2000) who found that under a young forest in the region the groundwater table was on average $1 \mathrm{~m}$ deeper than in the surrounding non-forested areas. They calculated a mean annual $E T$ rate of $712 \mathrm{~mm}$ for an actively growing black 
spruce community covering an area of $500 \times 500$ $\mathrm{m}$. On average the forest consumed $130 \mathrm{~mm}$ more water annually than it received from precipitation. The current estimates of $E T$ rates match these findings, yielding an average $620 \mathrm{~mm}$ annual ET for the forests in the groundwater discharge areas (this value may go up to $650 \mathrm{~mm}$ in certain pixels), which is about $80 \mathrm{~mm}$ more than the mean annual precipitation rate of the region.

The present, regionally representative mean annual recharge estimate of $75 \pm 50 \mathrm{~mm}$ is $50 \%$ higher than the previous $50 \mathrm{~mm} \mathrm{a}^{-1}$ estimate of Szilágyi (1994) and Szilágyi and Vörösmarty (1997) for the undisturbed (before groundwater declines took place) 1951-1970 period, although the error bounds include the latter estimate. Precipitation has remained practically the same over the two periods: $560 \mathrm{~mm}$ for $1951-1970$, and $550 \mathrm{~mm}$ for 2000 -2008 , however its distribution may have changed within the year (Tab. 1), thus influencing the resulting recharge rates. In the complex model of Szilágyi (1994) recharged water in the 1951-1970 period could only leave the area through seepage toward the Danube and the Tisza Rivers. In reality, however, the area is drained by many smaller streams and canals (Fig. 2) the effect of which included in the present recharge estimate. Major et al. (1991), lacking continuous discharge measurements on the small streams of the plateau, estimated this drainage to be $12 \mathrm{~mm}$ annually for the southern part of the region. Adding to this number the estimated (Davideszné, 1991) induced seepage of 10-20 mm annually from the unconfined groundwater system toward the underlying semi-confined one, due to a significant level of water extraction from the latter aquifer (becoming significant from the 1970s on (Pálfai, 2010), the two estimates, i.e., $75 \pm 50$ and $77 \mathrm{~mm} \mathrm{a}^{-1}$, match very closely. The induced seepage in general lowers the unconfined groundwater level leading to reduced soil moisture and therefore to reduced plant transpiration and so to increased recharge. Interestingly, the intervening 1970-1995 period is the one when precipitation decreased by about $7-8 \%$, and semi-confined groundwater extractions grew three-fold, leading predominantly to the reported 2-3 $\mathrm{m}$ unconfined groundwater level decline over the same period. To a lesser extent, increases in forested areas with their enhanced ET rates also contributed to the decline (Szilágyi, 1994).

The estimated mean annual recharge rate of $75 \pm$ $\pm 50 \mathrm{~mm}$ in the sand plateau is practically identical to that $(73 \pm 50 \mathrm{~mm}$ or $14 \pm 9 \%$ of the precipita- tion) of another, regionally significant, high permeability area, the Sand Hills of Nebraska, USA, the largest sand-dune region of the western hemisphere with a similar continental climate (mean temperature of $10^{\circ} \mathrm{C}$, and annual precipitation of $533 \mathrm{~mm}$ ), obtained with the same method (Szilágyi et al., 2011). In the Sand Hills these recharge estimates were corroborated by findings of Clover (1972) and Chen and Chen (2004) who, via calibrating a hydrogeology model of the unconfined groundwater system against observed groundwater-table elevations and stream discharges, reported an estimated mean annual recharge rate of $69 \mathrm{~mm}$ or $13 \%$ of precipitation in the central part of the region.

In summary, it can be stated that the present method may be applicable for estimating spatially distributed mean annual recharge rates in sandy areas of the world where basic climate data (precipitation, air temperature and humidity, global radiation or sunshine duration) for the past decade (the temporal coverage of the MODIS data) are available. The WREVAP FORTRAN code, with the corresponding documentation, can be downloaded from the personal website of the first author (snr.unl.edu/szilagyi/szilagyi.htm). The advantage of the present method of estimating mean annual recharge rates is that it (a) provides spatially varying values, thus the effect of land use and vegetation distribution to recharge rates becomes identifiable; (b) requires only typically easily accessible remotely sensed and standard climate data, and; (c) is self-calibrating. The only serious disadvantage of the present method is that the resulting rechargerate estimates will have a high associated uncertainty level in arid and semi-arid regions where a large portion of the precipitation ends up as ET.

Acknowledgments: This work has been supported by a) the Hungarian Scientific Research Fund (OTKA, \#77364); b) contribution of the Agricultural Research Division of the University of Nebraska; (c) the New Hungary Development Plan (Project ID: TÁMOP-4.2.1/B-09/1/KMR-2010-0002) in connection with the scientific program "Development of quality-oriented and harmonized R + D + I strategy and functional model at BME" project.

\section{REFERENCES}

BRUTSAERT W., 1982: Evaporation into the Atmosphere: Theory, History, and Applications. D. Reidel, Dordrecht, the Netherlands.

CHEN X., CHEN X., 2004: Simulating the effects of reduced precipitation on groundwater and streamflow in the Nebraska Sand Hills. J. Water Resour. Assoc., 40, 2, 419-430. 
CLOVER R. E., 1972: Deep percolation in a Sand Hills area. J. Water Resour. Assoc., 8, 2, 399-400.

DAVIDESZNÉ D. K., 1991: Hydrogeological model of Hungary (in Hungarian). VITUKI Report 712/1, Budapest.

DINGMAN S. L., 2002: Physical Hydrology. Prentice Hall, Upper Saddle River, ISBN 0130996955.

EUROPEAN ENVIRONMENT AGENCY, 1994: CORINE Land Cover Technical Guide.

MAJOR P., 1976: Groundwater balance investigations in flat lands. 2. Piezometer readings. (In Hungarian.) VITUKI Report, Budapest.

MAJOR G., MAJOR P., VARGAY Z., 1991: The effect of drainage conditions on the observed groundwater level changes within the Danube-Tisza region. (In Hungarian.) Vízügyi Közl., 73, 2, 142-152.

MORTON F., RICARD F., FOGARASI S., 1985: Operational estimates of areal evapotranspiration and lake evaporation Program WREVAP. National Hydrological Research Institute Paper \#24, Ottawa, Ontario, Canada.

MORTON F., 1983: Operational estimates of areal evapotranspiration and their significance to the science and practice of hydrology. J. Hydrol., 66, 1-76.

MÓRICZ N., 2010: Water-balance study of a groundwaterdependent oak forest, Acta Silv. Ling. Hung., 6, 49-66.

PÁLFAI I., 2010: Water-balance characteristics of the DanubeTisza interfluvial region. (In Hungarian.) Hidrol. Közl., 90, $1,40-44$.

PÉCZELY G., 1981: Éghajlattan. (Climatology.) (In Hungarian.) Tankönyvkiadó, Budapest.

PRIESTLEY C., TAYLOR R., 1972: On the assessment of surface heat flux and evaporation using large-scale parameters. Monthly Weather Rev., 100, 81-92.
STELCZER K., 2000: Hydological Bases of Water Resources Management. (In Hungarian.) ELTE Eotvos Kiado, Budapest, Hungary.

SZILÁGYI J., 1994: Water-balance modeling in a changing environment: reductions in unconfined aquifer levels in the area between the Danube and Tisza Rivers in Hungary. [Master's Thesis.] University of New Hampshire, Durham, New Hampshire, USA.

SZILÁGYI J., JÓZSA J., 2009: Estimating spatially distributed monthly evapotranspiration rates by linear transformations of MODIS daytime land surface temperature data. Hydrol. Earth System Sci., 13, 5, 629-637.

SZILÁGYI J., KOVÁCS A., 2010: Complementaryrelationship-based evapotranspiration mapping (CREMAP) technique for Hungary. Periodica Polytech., 54, 2, 95-100.

SZILÁGYI J., KOVÁCS A., 2011: A calibration-free evapotranspiration mapping technique for spatially-distributed regional-scale hydrologic modeling. J. Hydrol. Hydromech., 59, 2011, 2, 118-130.

SZILÁGYI J., VÖRÖSMARTY C., 1997: Modelling unconfined aquifer level reductions in the area between the Danube and Tisza Rivers in Hungary. J. Hydrol. Hydromech., $45,5,328-347$.

SZILÁGYI J., KOVÁCS A., JÓZSA J., 2011: A calibrationfree evapotranspiration mapping (CREMAP) technique, in Labedzki, L. (Ed.) Evapotranspiration (http://www. intechopen.com/books/show/title/evapotranspiration). Vienna, Austria, INTECH, ISBN: 978-953-307-251-7.

Received 12 November 2010 Accepted 19 October 2011 